\title{
Shining Examples of Service When the Lights Went Out: Hotel Employees and Service Recovery During the Blackout of 2003
}

By

\section{Robert J. Kwortnik}

(published in the Journal of Hospitality and Leisure Marketing (2006), 14 (2), pp. 23-45.)

\begin{abstract}
The electrical outage in the summer of 2003 that interrupted power to thousands of hotels wrought a variety of facilities failures and service-process problems. Fortunately, strong servicerecovery efforts from hotel employees mitigated the worst of the blackout's effects. Using survey data from hotel managers who experienced the blackout, this study highlights those employee actions that most contributed to immediate service recovery; however, the study also reveals limited organizational learning or efforts to failsafe hospitality service from the eventuality of future power failures.
\end{abstract}

\section{Key words}

blackout, hotels, service failure, service recovery, service quality, service employees

Robert J. Kwortnik, Ph.D., is an assistant professor of marketing at the School of Hotel Administration, Cornell University. All correspondence should be sent to Robert J. Kwortnik at 545 Statler Hall, School of Hotel Administration, Cornell University, Ithaca, NY 14853 (email: rik34@cornell.edu). This research was made possible by Smith Travel Research and the Center for Hospitality Research at Cornell University. 


\section{Shining Examples of Service When the Lights Went Out: Hotel Employees and Service Recovery During the Blackout of 2003}

"We'll leave the light on for you." Motel 6's advertising slogan is one of the most memorable in the lodging industry and a catchphrase of reliability. But in the late afternoon on August 14, 2003, the lights went off at a number of Motel 6 properties - as well as thousands of other hotels - across northeastern United States and southeastern Canada following the largest power failure in North American history. Some hotels were without electricity for as long as two days. At many hotels, emergency power also failed, mostly when batteries died. Key operating systems were shut down, including air conditioning, guest room lights, computer networks, cooking and refrigeration systems, and elevators. Some hotels completely lost access to a potable water supply - including running water for sanitary facilities (Kwortnik, 2005).

No sooner had power been restored and hotel operations returned to normal than images of the event emerged in the media, images that tended toward the unfavorable, such as hotel guests sleeping on the sidewalk in New York City's Times Square because they were not permitted into their rooms. The industry quickly responded with a different set of images; at least one hotel chain countered negative media with a press release offering examples of extraordinary service during the blackout and praising employees for their efforts to ensure guest safety and comfort (Business Editors/Travel Writers, 2003).

Evidence, both anecdotal and empirical (Kwortnik, 2005), suggested that what made the blackout far less damaging than it otherwise might have been for many hotels was not formal emergency preparedness, but instead the informal and improvised actions of employees. Hotel staff members managed to operate as many systems as possible - often manually. This included escorting guests to their rooms, carrying buckets of water for sanitary purposes, and handing out flashlights and light sticks. Some hotels that lost the use of their food-and-beverage equipment set up barbeques and cold food buffets, and even gave away food rather than allow it to spoil. Though service quality suffered at many hotels due to facilities failures and process problems, service recovery efforts by responsive, empathetic hospitality professionals mitigated the worst effects of the blackout. In short, when the lights went out, hotel employees shined.

One might dismiss common acts of courtesy and customer service during extraordinary situations as what services employees are expected to do; however, the importance of these behaviors clearly emerges when cast against the backdrop of a service system that has all but ceased to function. It is during these services encounters, these "moments of truth" (Zeithaml and Bitner, 2003, p. 99) that customers are won or lost - and that advocates for or adversaries of the brand are created. Given the strong influence of word-of-mouth promotion in the hospitality industry, managers should recognize that leaving such "real-time marketing" to chance places the brand at risk; hence, service recovery should be as much a planned marketing activity as advertising or customer-relationship management.

This article focuses on service recovery actions taken during the blackout of 2003 with the objective of identifying employee service behaviors that were most important for maintaining and enhancing hospitality service quality. To support this objective, a review of conceptual and empirical work on service recovery follows. This serves as a backdrop for the analysis of data culled from a survey of hotel managers whose properties were directly affected by the blackout. 
Based on findings from this analysis, this article concludes with a discussion about how to better manage hospitality-service recovery before, during, and after extraordinary situations.

\section{Service Recovery}

When service fails, managers need a plan of action for response. Although the typically unexpected nature of service failures may preclude planning for recovery in certain instances, services-marketing scholars advocate developing guidelines and strategies for recovery, as opposed to dealing with problems on an ad hoc basis (Hart, Heskett, and Sasser, 1990; Smith, Bolton, and Wagner, 1999; Tax and Brown, 1998; Zeithaml and Bitner, 2003). The reasons for this are many. Research has shown that customers often pay more attention to and are more emotionally involved in a firm's service recovery efforts than the original service encounter; further, failure to recover can create more dissatisfaction than the original failure (Bitner, Booms, and Tetreault 1990; Tax and Brown, 1998). On the other hand, successful service recovery can mitigate customer dissatisfaction (Smith et al., 1999), and in some cases even lead to a level of satisfaction that is higher than if the service had been performed correctly in the first place - a phenomenon dubbed the "service recovery paradox" (Hart et al., 1990; Smith and Bolton, 1998). In sum, effective service recovery can reduce customer dissatisfaction and defection, and superlative recovery can even enhance customer satisfaction and loyalty despite an initial failure.

Service failures are unavoidable because of the high "people factor" of services and the inherent variability in customer expectations and service performance this brings (Susskind, 2002). Planned service recovery is, therefore, vital for maintaining service quality. Some researchers characterize service recovery as a core dimension of service quality, suggesting that customers must be confident that if something goes wrong or the unexpected happens, the service provider will promptly help the customer to regain control and will assist in finding a remedy (Gronroos, 1988).

Zeithaml and Bitner (2003) developed a model of service recovery strategies that offers valuable practical insights for hospitality managers. They conceptualized service recovery as a cyclical process: a service failure should immediately be followed by solicited customer communication about the problem and prompt, fair problem resolution by the service provider that facilitates service recovery and customer retention. Furthermore, built into the service recovery system should be processes for tracking problems and resolution efforts that encourage organizational learning and the eventual correction of the source of the problem ("fail-safe the service"). Service recovery, therefore, is successful both when it fixes the customer by righting a wrong and also when it fixes the service by reducing the chances that the wrong will happen again to this or any other customer. In this way, service recovery becomes both customerrelationship and total-quality management initiatives simultaneously.

This model of service recovery underscores the importance of a strategic approach for responding to service failures. In addition to ensuring that customers have the means to communicate with service providers about problems and that failures and recovery are carefully tracked, a service-recovery strategy should include contingency plans, procedures for how to respond to service failures, and processes for using failure/recovery data to improve the service system. However, with a few exceptions (e.g., Hampton Inn's service guarantee program or the famed Ritz-Carlton approach to guest complaint handling) hospitality companies infrequently take a strategic approach to service recovery and, consequently, miss opportunities to strengthen bonds with customers or to enhance organizational learning (Tax and Brown, 1998). Evidence of 
this is found in the variety of service failures - many of which could have been anticipated encountered by hotel customers during the blackout of 2003, coupled with the limited use of emergency plans versus management judgment and "winging it" during the event. Moreover, surprisingly few hotel managers indicated that changes to emergency plans would be made in the aftermath of the blackout (Kwortnik, 2005)

When service fails, customers base their satisfaction evaluations on the perceived fairness of the recovery effort and on the entire set of service encounters relative to their expectations. According to one model that is particularly appropriate for the hospitality context, expectations are not a specific point or level, but rather are a range (Zeithaml, Berry, and Parasuraman, 1993). Cadotte and Turgeon (1988) referred to this range as a "zone of indifference," and suggested that for different service attributes, the shape of the zone will likewise differ. For example, the zone of indifference for attributes they labeled as "satisfiers," such as hotel lobbies, is likely to be relatively wide and have a low upper and lower threshold. That is, on the lower end of the range, modest performance on the attribute is unlikely to produce dissatisfaction, whereas above average performance on the attribute (e.g., a wide, well-lit atrium lobby) is likely to exceed the zone of indifference on the high end and lead to high satisfaction. In contrast, the zone of indifference for "performance criticals" is likely to be considerably smaller than for satisfiers. Furthermore, performance criticals are equally likely to engender satisfaction or dissatisfaction if performance is outside the zone. Guestroom cleanliness is a good example. Guests are unlikely to be happy with cleanliness levels that are just below their zone of indifference; on the other hand, clean rooms that exceed the norm may be especially pleasing. Zeithaml and Bitner (2003) discussed a conceptually similar idea they called the "zone of tolerance."

Managers can estimate the boundaries of the zone of tolerance through market research or even a good monitoring system for customer praise and complaints. However, events such as the blackout or the 9/11 tragedy (see Taylor and Enz, 2002; Knable, 2002) are extraordinary situational factors that customers usually assess as beyond the control of the service provider and that, consequently, redefine the zone, typically by lowering the zone's boundaries and widening the range (Zeithaml and Bitner, 2003). This is why hotel managers generally believed that guests were accepting of the lack of guestroom lighting during the blackout and were even delighted by the availability of flashlights and glowsticks (Kwortnik, 2005). Under normal power conditions, such a service failure would be a dissatisfier and the lack of it would not be tolerated. Kwortnik (2005) reported that hotel managers generally believed that guests were satisfied - and even delighted - with service levels during the blackout, despite the many facilities failures and process problems. Such a belief assumed that guests truly did perceive the myriad service failures that resulted from the loss of power as unexpected and beyond the control of hotel management. However, evidence of the causes of dissatisfaction during the blackout suggests that hotel guests' zones of tolerance for some service features (e.g., emergency lighting, elevators, and air conditioning) may have changed very little. Consequently, service performance on these attributes fell below the "adequate service" level and demanded effective service recovery. Whether this was achieved is the focus of the analysis and discussion that follows.

\section{Methodology}

This study uses online survey data collected from hotel managers who experienced the blackout of 2003. The online survey approach was chosen for a number of reasons, including low cost and high flexibility; i.e., branching questions embedded in the survey could 
unobtrusively direct respondents to different sections based on their responses to qualifying questions. However, the main reason for using an online survey was because speed of data collection was deemed important for data quality - by contacting managers as soon as possible after the blackout, recall errors and biases would be reduced. Thus, the first email invitation to participate in the survey was sent out five weeks after the blackout, with a follow-up email sent to non-responders less that a week later, for a total data collection window of under two weeks. The emails explained the purpose of the study and provided a clickable hyperlink to the online survey and a password unique to each respondent. As an incentive to participate, completed surveys were entered into a lottery, with five respondents chosen at random to receive complimentary one-year subscriptions to a hospitality-related research journal.

The sample contained 667 email addresses for hotels that were identified as being within the blackout region. The contacts were obtained from Smith Travel Research (STR), an independent research firm that tracks lodging performance data for North American hotels. STR also provided descriptive data for each hotel (e.g., chain affiliation and quality tier). The sample tends to over-represent larger, chain-affiliated urban hotels at the upper end of the quality scale (see Exhibit 1). Because analysis revealed that hotels of this type fared better during the blackout, the findings derived from the data are conservative and underestimate the true severity of the blackout on the lodging industry.

\section{Insert Exhibit 1 About Here}

Managers from 147 hotels across the region affected by the power failure (the U.S. states of Connecticut, Massachusetts, Michigan, New Jersey, New York, Ohio, Pennsylvania, and Vermont, and the Canadian province of Ontario) responded to the survey; 93 of these managers reported that their hotels lost power; thus, the effective response rate for the survey was $13.9 \%$ (93/667). Although this response rate is relatively low, a high response rate, though desirable, was not expected or necessary for this study for the following reasons. First, because the sample was not representative of the overall hotel population, concerns about non-response are less important because potential bias is already a factor (Krosnick, 1999). Second, research on internet-based surveys reveals considerable variance in response rates. Though mean response rates were around 35\% for online surveys conducted in the late 1990s (see Cobanoglu, Warde, and Moreo, 2001; Cook, Heath, and Thompson, 2000), more recent research suggest that response rates are dropping and are in the 20\% to 26\% range (see Bosnjak and Tuten, 2003; Deutskens, De Ruyter, Wetzels, and Oosterveld, 2004; Trouteaud, 2004). Finally, the survey was long (54 questions), the topic was potentially sensitive, and the contact email was not personalized - all factors that have been found to negatively affect response rates for internet surveys (Cook et al, 2000; Deutskens et al, 2004). In sum, a non-representative sample and potential non-response bias limits the generalizability of the findings reported here, though this is less of an issue given the main objective of this study of highlighting strong service recovery efforts during the blackout.

In addition to media reports, exploratory telephone interviews with hotel managers who experienced the blackout suggested that the effects of the event on hotel operations, employees, and guests varied greatly. Therefore, the questionnaire was designed to obtain a revealing picture 
of respondents' experiences. This was accomplished with 14 open-ended questions, as well as comment dialogue boxes appended to many of the 40 closed-end questions. The majority of the questions asked respondents to describe in their own words what happened, e.g., which systems failed, how facilities and processes were affected, how staff responded and improvised, how guests acted, etc. Some questions were also informed by the literature on service quality and service recovery, and asked managers to provide examples of, for example, responsive or empathetic acts by staff.

The survey netted more than 60 pages of rich comment data that revealed the unique challenges faced by hotels across lodging sectors and how managers and employees responded to these challenges. Managers recounted detailed stories and examples of their experiences during the blackout. This data was content analyzed by grouping similar comments into categories and then determining frequencies of activities, behaviors, thoughts, feelings, and the like. In addition to content categories, the data was mined for vivid examples of events and actions. These examples are presented verbatim throughout the next section of this paper to add further support for the inductive conclusions that emerged from the content analysis.

\section{Findings}

When power failed across the blackout region, hotels lost the functionality of key aspects of the service delivery system (Kwortnik, 2005). Particularly hard hit were tangible elements of the lodging experience. Hotels were without power for an average of 16 hours, or throughout the night. For nearly $90 \%$ of hotels, air conditioning and guestroom lighting was out. At two out of three hotels, elevators, telephones, hot water, and bathroom facilities were at least somewhat affected by the outage. Also rendered inoperable in many hotels were elements needed for key service processes, such as computers for check-in/out, cooking systems, refrigeration, and potable water for F\&B service, key encoders for making guestroom keys, and emergency lighting for safe movement within the hotel. Incidence of these failures was higher for the smaller, midscale or economy hotels that relied on battery-powered backup systems versus generator-powered systems. Further, the facilities and process failures worsened as the duration of the blackout extended beyond a few hours and backup systems started to fail. The end result was that, a few hours after primary power failed and just as nightfall loomed, some hotels went completely dark. Not surprisingly, managers reported that sources of guest dissatisfaction were mostly related to service quality failures in terms of physical facilities. In contrast, customer service and the interaction with hotel employees was not a source of guest dissatisfaction.

With electrical power down, hotel managers had to rely on people power for service recovery. This included both the contribution of service staff, from housekeepers to managers, as well as the cooperation of guests. In terms of the former, data indicate that managers were overwhelmingly pleased with and proud of their employees for making a difficult situation far less so. The reasons for this can be summed up by a simple statement offered by one manager: "Employees went above and beyond the call of duty to ensure our guests' safety and comfort. They put 'service above self."”

\section{Managers’ Perceptions of Service Levels.}


Managers were asked to rate the level of service that hotel staff members provided to guests during the blackout compared to typical service levels. Nearly two-thirds of respondents said that staff service levels exceeded the norm, and half of these managers believed service levels were greatly exceeded. Only $10 \%$ of respondents felt that service levels fell short. There were no differences in the perceptions of managers regarding service-levels based on whether their hotels had standby power available or not, or based on the number of hours the hotels were without power. However, managers at midscale and economy hotels were somewhat more likely to feel that typical services levels were exceeded during the blackout, whereas managers at upscale and upper-upscale hotels were somewhat more likely to feel that service levels fell short $\left(\chi^{2}(1)=3.08, \mathrm{p}=.08\right)$.

Analysis of service-level perceptions across geographic areas suggests that managers based their ratings of service not only on the actual level provided, but also on the effort required to provide it. For example, managers in southern Michigan experienced the dual challenge of a long blackout and interruption in the water supply. Their employees had to go to great lengths to provide guests with the essentials in order to produce a hospitality experience that would otherwise be the norm. One Detroit-based manager noted: "The entire staff mobilized to cater to our guests' needs, and I mean basic needs, like food and water. All of the restaurants in the area closed during the blackout and this caused a major problem for guests who had no gas for their vehicles and nowhere to eat."

\section{Service Recovery: Doing Normal Things Well When Things Are Not Normal}

With power out, extra staff and management attention was often required to maintain service delivery and ensure a safe, calm hospitality environment. One manager at an 80-room midscale hotel commented, "Normally one person can run the entire hotel; in a blackout situation, the demand is 10 -fold." Processes most impacted in this regard were food service and guest check-in. Check-in became especially time and labor intensive, with guests needing room escorts, help carrying luggage up stairs if elevators were inoperable, and someone to unlock doors if room keys were unavailable. Despite the additional labor required to keep hotels running, though, most managers felt they were adequately staffed.

When asked to give examples of employee behavior that reflected the type of service level provided during the blackout, some managers described extraordinary service that "went the extra mile.” For instance, there was one employee who siphoned gasoline from the hotel van in order to provide a guest whose car was on empty with enough fuel to get to a service station. An employee of another hotel rode his bicycle 12 miles to work to lend his support even though he was not scheduled to work. Managers at several hotels stayed up through the night to see to guest needs and ensure their safety and comfort. However, manager comments reveal that it was not so much the extraordinary efforts of employees that typified personal service during the blackout as it was the culmination of little things - from escorting guests to rooms to being empathetic to the basic needs of stranded travelers.

Content analysis of manager descriptions of employee behavior during the blackout produced 120 different examples of things that hotel staff did to keep the service system running. This analysis suggests that employee behaviors can be grouped into five categories that managers felt were important: 1) being there; 2) professionalism; 3) personal attention; 4) food service; and, 5) communication. It is notable that no single category stood out as dominant in 
terms of comment frequency. This suggests that managers felt employee behaviors represented by these categories were of equal importance in maintaining service levels.

The Importance of Being There. Managers clearly valued that employees simply were there - that callouts were not a problem, but instead members of the "team" came in early, stayed late, or stayed over, and often without having to be asked. This was all the more appreciated given the challenges some people faced in getting to work. One manager noted, "All employees present at the time of the blackout stayed to help out wherever needed. Nobody went home at the end of their shift or until they were not required. All departments jumped in and worked as a team, helping wherever needed." Said another manager, "Employees came in several hours early for shifts to help out. All managers moved into [the] hotel for the day. Staff and managers walked halls to reassure guests; staff rode elevators with guests nervous about back up power." Finally, another manager explained, "Sales staff and management stayed all night and walked around public areas to speak with guests and attend to any of their needs and requirements. Spa staff stayed to provide complimentary back and neck massages to guests.” In sum, though the hotel facility and service processes had become unreliable, the extra efforts of hotel employees helped to mitigate this variance in the service delivery system.

"Being there" also meant being visible to guests to provide personal assistance or just assurance. Staff mingled with guests in the lobby, used lanterns to direct guests in parking garages, or shared meals with guests, which created a "family environment." Several managers described instituting regular patrols on guest floors, or having staff on each floor to answer questions, attend to needs, and provide guest room access. Respondents felt that additional management coverage was especially important for reassuring guests about their care and safety.

The Importance of Professionalism. Managers praised employees for a high level of professionalism that was exhibited in many ways, though three main behaviors emerged: 1) exhibiting professional demeanor; 2) fostering team spirit; and, 3) working flexibly.

Exhibiting professional demeanor. Managers commented on the importance of continuing to play hospitality roles well, even though the blackout produced a significant change to the service-delivery script. Employees were lauded for being friendly, positive, helpful, and dignified, and for "keeping a cool head on their shoulders," despite having to work in hot conditions and perform tasks that were often unpleasant. Actions in support of this professional manner included following procedures, willingness to help guests with most any request, and frequent and frank communication with guests. One manager gave this example:

Fortunately, almost all managers were on site when the power went out. We met and created a plan that included ensuring a [senior] member of our team was in the lobby at all times to answer questions, provide assistance, and ensure that panic did not set in. All managers were calm, which meant all staff were calm. Everyone maintained a sense of humor, which set the tone for the guests.

Fostering team spirit. Managers also lauded the team spirit of their employees. One manager developed this idea: "Like any crisis, this was a great test of our team's ability to come together and perform at a higher level than normal, and it's also a great opportunity to interact with guests and show them how we can respond to problems and challenges.” Such comments were supported by many illustrations of sacrifice and of willingness to perform whatever tasks were needed to meet guests’ needs. 
Working flexibly. Managers were particularly impressed with staff who broke the bounds of their job descriptions to work in departments other than their own or who changed procedures because circumstances demanded it. Examples of such behavior included managers performing housekeeping duties or assisting bellmen by carrying luggage, and front desk clerks cooking on gas grills to feed guests. Commented one manager, "Every employee did way beyond what was necessary to insure the safety and welfare of the guests and fellow co-workers. Housemen served ice water to guests in the lobby, bellman helped make up cots with room attendants, etc."

In addition to flexibility in job roles, employees were flexible in thinking about how to perform jobs. This meant coming up with solutions to service failures. This also meant working hard and working differently. One manager described relocating an in-process group meeting from a room without light to one with natural light coming through windows: "This involved a significant amount of materials and happened very quickly. We provided options to continue the AV portion of meeting by utilizing a power circuit on the emergency generator.” A second manager described helping to keep children occupied: "Banquet rooms were opened and supervised kids activities were conducted. Kids movies were played using backup power."

The Importance of Personal Attention. Hotel staff provided a high level of personal attention to guests during the blackout, the positive effect of which was magnified by empathy for "stranded" guests. The most common act of personal attention provided during the blackout was room escorts. One manager remarked, "All guests needing to walk upstairs were personally escorted to their rooms. All associates [were] given master keys should individual guest keys fail. [Corridor] monitors offered assistance if needed. Personal attention was the key.” Another manager told a similar story: "My employees were extremely helpful, positive and very focused on making our guests feel comfortable \& safe. The bell persons and managers in general did a lot of walking the stairwells with guests and their luggage as well as completing safety tours of building every 45 minutes."

Employees also provided door-to-door deliveries of news, luggage, and supplies. Extra staff was often dedicated to these tasks, as well as to visiting each guestroom to ensure that everything was all right. Several managers described giving special attention to guests who most needed it, such as people with disabilities, the elderly, and guests traveling with children. One hotel assigned a manager specifically for such guests. At another hotel, management assured that rooms occupied by guests with disabilities were called on every few hours.

Managers provided numerous examples of considerate, personalized efforts by hotel employees on behalf of guests. For example, one manager offered this list:

Escorting guests to their rooms with flashlights. Calling airlines throughout the night to check on specific flights while guests slept. "Wake up knocks" instead of "wake up calls." Driving guests to the airport because taxis did not want to use their gasoline. Guests charging their cell phones off associate cars....

No doubt, more instances of empathetic, personalized attention took place during the blackout that were not observed by management.

The Importance of Food Service. Hotel managers frequently referred to the ability to provide F\&B as indicative of the level of service delivered during the blackout. The varied ways by which hotels recovered the food service function represents one of the more dramatic success stories of the blackout. Food service is labor intensive, and with cooking systems down at nearly three out of four hotels, and refrigeration similarly affected, for hotel employees to offer even 
something basic required effort and creativity. F\&B outcomes may have been ordinary relative to typical hotel hospitality, but given the lack of inputs to the process, that F\&B was available at all was extraordinary. Noted one respondent:

We held a barbeque for all our guests for free outside by our pool area. We provided candles and flashlights to all our staff and guests. We gave all guests free drinks including liquor. We had a party and the guest loved it. The comment cards sent to [the corporate] office were fantastic.

The use of outdoor grills was the most frequently mentioned substitute for closed kitchens. Nearly one-quarter of the hotels hosted barbeques, and several managers described the atmosphere as festive, with pool-side or patio parties ensuing. According to one manager, the availability of outdoor grills meant that meals were not delayed and chefs were able to provide a relatively normal menu. Another manager of a hotel without F\&B facilities recounted the satisfaction of guests who did not expect a "lodging only" establishment to feed them:

Restaurants in the area closed during the blackout and this caused a major problem for [those] who had no gas for their vehicles and nowhere to eat. My staff found a supermarket that hadn't closed down and purchased bulk hot dogs and hamburgers as well as condiments and bottled water. They barbequed ... and also served sandwiches at the desk, much to the pleasure of our "stranded" guests. ... That is why I'm very proud of the above-and-beyond performance of my staff, who are not cooks or food service employees.

Many hotels also gave out free beverages during the blackout, especially bottled water, juice, and soda. Some managers comped beer and wine as well. One manager said that a main source of dissatisfaction for guests was the decision not to open the bar.

The Importance of Communication. During the blackout, hotel guests were left in the dark - literally and figuratively. Without power to phones, televisions, and computers, news of the event was hard to come by. Managers described the importance of communication as a prime example of how employees were responsive to guest needs - in this case, the need for news. Employee communication took on a variety of forms, but broadly can be categorized as communication with guests within the hotel or facilitating guests' communication outside the hotel. Key to the latter was allowing guests to use personal cellular phones.

For communications within the hotel, employees came up with creative solutions in the effort to provide news updates for guests:

- news updates announced on a bullhorn

- electronic news updates conveyed by a laptop computer at the front desk;

- radios rigged to broadcast in public areas;

- intercom updates on the outage and its impact;

- paper updates that were slid under guests' doors twice per day;

- televisions in public spaces tuned to informational channels;

- telephone information provided to guests due to arrive in a blackout destination;

- telephoned news updates made to guestrooms (while phones were operable);

- management greeters in the lobby, who were relayed news by staff listening on car or portable radios or information gathered by cell phone; 
- table-to-table news updates during dinner provided by the managers.

Providing guests with access to current news and information offered the benefits of less uncertainty for them and a sense of greater control over their situation, as well as reduced chance that guests would blame the hotel for their predicament, which would impact their satisfaction with their stay. Managers at $85 \%$ of the hotels said that guests most often attributed blame for inconveniences experienced at the hotel to a third party (e.g., electrical utility companies or the government). In contrast, managers at less than $9 \%$ of the hotels said guests were blaming hotel management or staff. In all likelihood, this hotel-focused blame would have been higher had guests not received timely information about the blackout. This finding also suggests that guests viewed the blackout as a situational factor beyond the control of the hotel, which means their "zone of tolerance" for service problems likely was wider and the thresholds for adequate and desired service were reduced (Zeithaml and Bitner, 2003). Evidence in support of this is detailed in the following sections.

\section{The Guest Experience}

Most managers believed that their hotels provided a positive guest experience during the blackout. Some examples of these perceptions:

Many guests told us we were operating at a level of service of a 4 star, even though we are a 2 star economy hotel. We made an impression on our guests that I know they will remember and hopefully [will] gain us their repeat business.

I received a great amount of guest feedback. All guests emphasized what a great job we all did to handle the blackout. I even played football in the parking lot with some guests. It was an unusual circumstance that we made the best of.

The actions of the staff during the power outage greatly enhanced the comfort of our guests that evening and have resulted in many positive comments from guests. Due to our location we had many customers check-in from the city hotels who were not able accommodate the needs of their guests.

In addition to believing that service levels exceeded the norm, managers believed that service quality was high overall. Results reported in Exhibit 2 show that managers especially thought that the hotel organization (management and staff) showed "sincere interest in solving guest problems," "inspired confidence and trust in guests," "helped make guests feel safe," and "provided personalized attention." However, responsiveness and empathy are only two dimensions - and usually not the key determinants - of service quality in the hospitality context; rather, research shows that reliability, tangibles, and assurance are the key service quality factors (see Kwortnik, 2005). Although hotel employees may have helped to compensate for a lack of assurance wrought by failed emergency systems, efforts to compensate for service quality in terms of reliability and tangibles proved far more challenging.

Insert Exhibit 2 About Here 


\section{Managing the Blackout: A Co-Production}

An essential characteristic of services such as lodging is that they are co-produced experiences. Although the service provider may often control production of the service, there are times when the customer becomes a more active participant and directly influences his or her own satisfaction with the experience. The blackout was one of those times.

Managers recounted examples of increased interaction between staff and guests and among the guests themselves during the blackout. For example, the lobby at many of the affected hotels became a meeting place where information about the blackout was shared. One manager noted that guests stayed in the lobby playing games with other guests until they went to bed. A few managers also told of guests who offered to lend a hand. The willingness of guests to do things differently and to reframe their expectations in light of the circumstances helped to improve their own experience. One manager stated, "I would like to acknowledge not only the amazing service my staff rendered, but [also] the amazing attitude of our guests who as a whole helped us to help them maintain safety and security." Herein rests an important reason why the blackout event was not as bad as it might have otherwise been: many guests simply made the best of it, and in so doing, contributed to the positive experience of others, both guests and hotel staff. Open communication between management and guests appears to have facilitated this positive co-production.

\section{The Effects of Service Failure and Recovery}

Hotels that lost power during the blackout suffered negative effects on the bottom line in terms of occupancy, average daily rate, RevPAR (revenue per available room) and profit and loss (Kwortnik, 2005). However, the long-term effects on these hotels are less clear. This is because negative media reports about hotel service failures may be offset by the service-recovery successes described here. To explore this question, managers were asked to assess effects of the blackout across three dimensions: image of their hotel, consumer choice for their hotel, and consumer confidence in the lodging industry overall.

Hotel image. When asked about the effect of the blackout on hotel image (positive, negative, or none), only one manager though this would be negative. The remaining respondents were evenly split in their belief that the blackout would have no impact or would improve their hotel's image. In fact, managers were significantly more likely to predict a positive effect on their hotel's image if they had lost power during the blackout than if they had not. More than two-thirds of managers from hotels that lost power anticipated a positive impact on hotel image from the event, versus only $22 \%$ of managers from hotels that did not lose power $\left(\chi^{2}(2)=27.78\right.$, $p$ $=.001$ ). Managers' comments reveal their general belief that guests were impressed with how these hotels handled service recovery during the event. One manager stated, "Our staff rallied around the challenge, improving our image with those guests who were here"; said another manager, "Several guests said they hope they get 'stuck' with us if it happens again.” Thus, managers generally believed their hotel had achieved the "service recovery paradox."

Consumer choice. Managers were similarly asked what they thought the impact of the blackout would be on the traveling public's choice of their hotel for lodging. Few managers thought the blackout would diminish the likelihood that a guest would choose their hotel. Rather, 
$43 \%$ of the managers thought the impact on choice would be positive, and 56\% predicted no impact. Once again, there were significant differences in opinions depending upon whether the respondent's hotel had lost power or not. Roughly one out of four managers of hotels that were not affected by the blackout predicted a positive effect of the event on choice of their hotel, but more than half of managers from hotels that lost power during the blackout predicted the same $\left(\chi^{2}(2)=27.78, \mathrm{p}=.001\right)$. Noted one manager in the latter group, "We took care of guests and they knew we went above and beyond to provide for their needs."

Consumer confidence. Finally, managers were asked about the blackout's effect on consumer confidence in the lodging industry as a safe, comfortable, and convenient source of overnight accommodations. Responses to this question were also positive, but less so than the responses about hotel image and choice. A small percentage of respondents (7.5\%) thought the effect of the blackout on consumer confidence in hotels would be negative, $41 \%$ thought the effect would be positive, and the remaining 51\% predicted no effect. However, unlike the hotel image and choice questions, there were no significant differences in predictions about consumer confidence between managers from hotels that lost power during the blackout versus managers from hotels that did not lose power.

Comment data suggest that one reason for this shift in opinion was that managers at hotels which lost power believed their hotel performed well during the blackout, but that "other hotels" did not. The most common targets for this blame were the "big boxes" in New York City. One manager said there was "too much publicity on the ... hotel in NY forcing its guests on the street. People assume this kind of activity is widespread.” In general, though, managers felt it was difficult to predict what the effect of the blackout would be on consumer confidence in the lodging industry because they perceived the blackout to be an extraordinary occurrence.

\section{Discussion}

The blackout of 2003 caused a range of service failures in hundreds of hotels and affecting thousands of guests. Some of these failures were just inconveniences, whereas others, such as nonfunctioning emergency systems, had potentially serious consequences. Fortunately, hotel managers were able to rely on their people to make up for shortcomings in planning, processes, and the physical plant. When guestrooms and public areas went dark, employees distributed flashlights and glow sticks. When elevators stopped running and room-key encoders failed, hotel staff escorted guests to their rooms, often hauling luggage up flights of stairs. When phones went silent, employees offered guests the use of personal cellular phones. When kitchencooking systems became inoperable, F\&B and other hotel staff improvised with pizza parties, barbeques, and cold buffets. Instead of wake-up calls, guests received wake-up knocks on their doors, and instead of voicemail, guests received handwritten phone messages. And when running water ceased, hotel management and staff personally flushed sanitary systems with water retrieved from the swimming pool. Indeed, when the lights when out, hospitality service providers shined.

Most hotel managers felt that service levels exceeded the norm, despite the difficulties faced in providing service essentials. Staff worked overtime, often volunteering to do so, and management stayed on premise during the event. The work was hard, and conditions were unpleasant, but hotel employees rose to the challenge in order to meet guests' needs and solve hotel problems. Hotel employees made an effort to be there, to act professionally, to provide personal attention and hospitality, and to facilitate communication. 
Researchers in the area of services marketing stress the importance of services employees to the customer experience by arguing that employees are the service, the brand, and the organization in the eyes of customers (Zeithaml and Bitner, 2003, p. 318). The blackout provided a context that strongly supports this view. In the aggregate and at the level of individual action, this employee service orientation was arguably one of the defining elements of the service delivery system that not only did not falter, but that hotel managers believe compensated for serious shortcomings in other areas.

The evidence offered by managers illustrating "service above self," as well as reports of positive customer feedback suggests that manager perceptions of service levels provided during the blackout are reasonable. However, service as perceived by the customer is multidimensional and not just a function of the interaction with service providers (Schneider and White, 2004). Customer-defined service quality also incorporates perceptions of service reliability and tangibility, i.e., the physical environment, which suffered greatly during the blackout. By analogy, the overall service experience at a restaurant for which the meal is undercooked and served on unclean dishes will not be perceived favorably by the customer, regardless of how good the table service is.

An important question, though one that will require future research to answer clearly, is whether guests perceived hotel-employee efforts during the blackout (or similar extraordinary events) as exceptional service or merely as what a hotel is expected to provide - even when circumstances are extraordinary. That is, how did guests reframe their zones of tolerance? Managers generally believed guest satisfaction was high during the blackout and that guest expectations were lower. Service should be assessed, though, not only in terms of effort, but also in terms of outcomes and expectations. Likewise, what may have been important to managers in terms of service provided by hotel staff may not have been as important to guests. Still, there is little disputing the vital contribution made by employees during the blackout to maintaining hotel operations and making the guest experience at the very least tolerable and more often far better.

Managers generally believed the longer-term impact of the blackout would be negligible - or positive. Managers whose hotels lost electrical power were especially likely to think this. This perception is questionable, given the high incidence of problems - especially the lack of basic amenities- that hotels experienced. But, it is also understandable in light of managers' beliefs that staff responsiveness and empathy more than made up for failures in the physical environment.

In sum, the evidence from managers' perceptions of the blackout is that most hotels were successful at service recovery. Moreover, in many cases, the service-recovery paradox was achieved, with guests supposedly even more satisfied and impressed with the hotel than they might otherwise have been if service had not failed in the first place. One of the limitations of this study, though, is that data directly assessing customer satisfaction and attitudes were not collected. Thus, whether hotel guests will respond similarly to a future blackout-type event, remains to be seen. Research on the recovery paradox shows that first-time service failures that are attributed to causes beyond the service provider's control may be forgiven, especially in light of successful recovery. However, additional, similar failures are perceived differently, even if recovery is again achieved (Maxham and Netemeyer, 2002). Although research on such "double deviations" typically analyzes customer evaluations of service recovery at the firm level, the proposition can be extended to the broader hospitality industry (and is worthy of future research). Though hotel customers may have forgiven the industry for not being well-prepared for the blackout of 2003, they may expect hotel owners and managers to have learned from the 
experience and be better prepared for the next time the lights go out. If the same types of service failures are repeated, hotel customers may be far less forgiving, regardless of hotel employees' best efforts to recover.

Findings from the present study show that a strategic approach to service recovery is not consistently applied in the lodging industry. Hotels welcomed complaints and acted quickly and fairly to resolve problems as best as possible under the circumstances. However, how much organizational learning really occurred from the recovery experience remains to be seen. Furthermore, the recovery effort was largely in the hands of employees. Rather than better fail safe the lodging service, hotel managers will continue to rely on employees to place "service above self” when the service system falters.

\section{Conclusion}

The blackout of 2003 was yet another example of an uncontrollable event disrupting hospitality service. Most hotels are ready to handle a short power failure of a few hours or less; but, most hotels are not well-prepared for an extended power failure, especially one that covers a lot of ground and that takes down critical systems, such as running water and air-conditioning or heat. While a dedicated, responsive, and empathetic staff can at least partially recover for failures along other dimensions of the service delivery system, the objective for hospitality providers should not be service recovery, but good or excellent service in the first place. thought:

Looking back on the experience during the blackout of 2003, a manager offered this final

I have gone through many emergencies in my 15 years as a hotel GM, but this was different in that the magnitude of the areas affected brought thoughts of potential terrorism to the minds of many including my own. It just helps us as a nation be better prepared for future emergencies and the reality that they CAN happen here.

\section{References}

Bitner, M. J., Booms, B. H., \& Tetreault, M. S. (1990). The service encounter: diagnosing favorable and unfavorable incidents. Journal of Marketing, 54 (January), 71-84.

Bosnjak, M. \& Tuten, T. L. (2003). Prepaid and promised incentives in web surveys: an experiment. Social Science Computer Review, 21 (Summer), 208-217.

Business Editors/Travel Writers (2003). Hilton family of hotels shine during recent power blackout. Business Wire, New York (August 21, 2003), 1.

Cadotte, E. R. \& Turgeon N. (1988). Key factors in hotel guest satisfaction. Cornell Hotel and Restaurant Administration Quarterly, 28 (February), 44-51.

Cobanoglu, C., Warde, B., \& Moreo, P. J. (2001). A comparison of mail, fax, and web-based survey methods. International Journal of Market Research, 43 (4), 441-452.

Cook, C., Heath, F., \& Thompson, R. L. (2000). A meta-analysis of response rates in web- or internet-based surveys. Educational and Psychological Measurement, 60 (December), 821-836. 
Deutskens, E., De Ruyter, K., Wetzels, M., \& Oosterveld, P. (2004). Response rate and response quality of internet-based surveys: an experimental study. Marketing Letters, 15 (1), 2136.

Gronroos, C. (1988). Service quality: the six criteria of good perceived service quality. Review of Business, 9, (Winter), 10-13.

Hart, C. W. L., Heskett, J. L., \& Sasser, Jr., W. E. (1990). The profitable art of service recovery. Harvard Business Review (July-August), 148-156.

Knable C. R. J. (2002). September 11 2001, recovering hospitality at ground zero. Cornell Hotel and Restaurant Administration Quarterly, Vol. 43, No. 5 (October), 11-26.

Krosnick, J. (1999). Survey research. Annual Review of Psychology, 50, 537-567.

Kwortnik, R. J. (2005). Safeguarding hospitality service when the unexpected happens: lessons learned from the blackout of '03. Cornell Hotel and Restaurant Administration Quarterly, 46 (February), 13-39.

Maxham, J. G. \& Netemeyer, R. G. (2002). A longitudinal study of complaining customers' evaluations of multiple service failures and recovery efforts. Journal of Marketing, 66 (October), pp. 57-71.

Schneider, B. \& White, S. S. (2004). Services Quality: Research Perspectives. (Thousand Oaks, CA: Sage).

Smith, A. K. \& Bolton, R. N. (1998). An experimental investigation of customer reactions to service failure and recovery encounters: paradox or peril? Journal of Service Research, 1 (August), 65-81.

Smith, A. K., Bolton R. N., \& Wagner J. (1999). A model of customer satisfaction with service encounters involving failure and recovery. Journal of Marketing Research, 36 (August 1999), 356-372.

Susskind, A. (2002). I Told You So! Restaurant customers' word-of-mouth communication patterns. Cornell Hotel and Restaurant Administration Quarterly, 43 (April), 75-85.

Tax, S. S. \& Brown, S. W. (1998). Recovering and learning from service failure. Sloan Management Review (Fall), 75-88.

Taylor, M. S. \& Enz, C. A. (2002). Voices from the field: general managers' responses to the events of September 11, 2001. Cornell Hotel and Restaurant Administration Quarterly, Vol. 43, No. 1 (February), 7-20.

Trouteaud, A. R. (2004). How you ask counts: a test of internet-related components of response rates to a web-based survey. Social Science Computer Review, 3 (Fall), 85-392.

Zeithaml, V. A., Berry L. L., \& Parasuraman, A (1993). The nature and determinants of customer expectations of service. Journal of the Academy of Marketing Science, 21, (1), $1-12$.

Zeithaml, V. A. \& Bitner M. J. (2003). Services Marketing: Integrating Customer Focus Across the Firm (New York: McGraw-Hill Irwin). 


\section{Exhibit 1: Sample Demographics}

\begin{tabular}{lccc}
\hline \multicolumn{4}{c}{ Survey Responses Categorized by Hotel Scale and Chain Affiliation } \\
\hline $\begin{array}{c}\text { STR scale \& chain } \\
\text { affiliation }\end{array}$ & $\begin{array}{c}\text { \% of Hotel } \\
\text { Census }\end{array}$ & $\begin{array}{c}\text { Blackout Survey } \\
\text { Responses }\end{array}$ & $\begin{array}{c}\text { \% of Blackout } \\
\text { Responses }\end{array}$ \\
\hline Upper Upscale Chain & $3.5 \%$ & 17 & $18.3 \%$ \\
Upscale Chain & $4.7 \%$ & 20 & $21.5 \%$ \\
Midscale w/ F\&B Chain & $9.7 \%$ & 12 & $12.9 \%$ \\
Midscale w/o F\&B Chain & $14.0 \%$ & 22 & $23.7 \%$ \\
Economy Chain & $20.5 \%$ & 5 & $5.4 \%$ \\
Independent & $47.7 \%$ & 17 & $18.3 \%$ \\
Total & $\mathbf{1 0 0 . 0 \%}$ & $\mathbf{9 3}$ & $\mathbf{1 0 0 . 0 \%}$ \\
\hline
\end{tabular}

\section{Survey Responses Categorized by Room Count}

\begin{tabular}{lccc} 
Room Category & \% of Hotel Census & Blackout Survey Responses & \% of Blackout Responses \\
\hline Less than 75 & $57.7 \%$ & 10 & $10.8 \%$ \\
75 to 149 & $29.9 \%$ & 43 & $46.2 \%$ \\
150 to 299 & $9.1 \%$ & 28 & $30.1 \%$ \\
300 to 499 & $2.3 \%$ & 6 & $6.5 \%$ \\
More than 500 & $1.0 \%$ & 6 & $6.5 \%$ \\
Total & $100.0 \%$ & 93 & $\mathbf{1 0 0 . 0 \%}$
\end{tabular}

Note: STR is Smith Travel Research; F\&B is food and beverage

\section{Exhibit 2: Managers' Perceptions of Service Quality During the Blackout}

\begin{tabular}{lc}
\hline \multicolumn{1}{c}{ Service Quality Factor } & Mean Score \\
\hline We showed a sincere interest in solving guest problems during the blackout. & $6.82(0.39)^{\mathrm{a}}$ \\
We inspired confidence and trust in guests during the blackout. & $6.70(0.64)^{\mathrm{b}}$ \\
We helped make guests feel safe during the blackout. & $6.68(0.73)^{\mathrm{b}, \mathrm{c}}$ \\
We gave guests personalized attention during the blackout. & $6.57(0.71)^{\mathrm{c}, \mathrm{d}}$ \\
We responded to guest requests in a timely manner during the blackout. & $6.54(0.65)^{\mathrm{d}}$ \\
We provided guests with reliable service during the blackout. & $6.44(0.74)^{\mathrm{d}}$ \\
We were prepared to deal with service demands during the blackout. & $5.62(1.24)^{\mathrm{e}}$ \\
& \\
\hline & \\
\hline & \\
Note: Mean scores are based individual managers' agreement with the statement using a scale where 1 = \\
Strongly Disagree, 2 = Disagree, 3 = Slightly Disagree, 4 = Undecided, 5 = Slightly Agree, 6 = Agree, 7 = \\
based on a paired samples t-test. Items with different letters that are significantly different; items with the \\
same letters are not significantly different.
\end{tabular}

